\title{
Chimpanzee included in the genus Homo? How Biology teachers from three Latin American countries conceive it.
}

\author{
Heslley M. SILVA ${ }^{\mathrm{a} 1}$, \\ Graça S. CARVALHO ${ }^{b}$ \\ ${ }^{a}$ University Center of Formiga, University of Itaúna, Augusto Moreira Street, 22 - Apt. 101, Itaúna City, \\ Minas Gerais State, Brazil, heslley@uniformg.edu.br \\ ${ }^{b}$ University of Minho, CIEC, Institute of education, Campus de Gualtar, Braga, Portugal, \\ graca@ie.uminho.pt
}

\begin{abstract}
This work intended to understand the biology teachers' conceptions about the humans' position regarding other animal species. It was carried out in three countries with contrasting secularism conditions: Argentina, Brazil and Uruguay. Teachers were asked to answer, in a Likert-type scale, to the question B7 of the European project BIOHEAD-CITIZEN: "The Chimpanzee should be included in the genus Homo, notably because $98.5 \%$ of its DNA is identical to that of Homo sapiens".. Results were analyzed within the KVP model framework and the Barbour's four categories of relationship between science knowledge and religion. The majority of teachers surveyed in the three countries rejected the idea of including the chimpanzee in the genus Homo, suggesting the conception of human beings having a special position in relation to other animal species, despite evidence of current molecular biology. The religiosity in all countries were similar, therefore no specific influence could be tested regarding the inclusion of chimpanzee in genus Homo. This study also indicates that it is important to study further the training of biology teachers in the three countries to verify how they are being trained and evaluate their knowledge regarding molecular biology, phylogeny and evolution.
\end{abstract}

Keywords: human origin, chimpanzee, evolution, religion, education

Conference Topic: Science Education

\section{INTRODUCTION}

The question of evolutionary association between chimpanzees and humans nowadays is seen by scientists as a matter of the past, therefore it should no longer be a subject of debate within the academic and educational actors. At first glance, by outward appearances, it may appear that these animal species are rather apart from each other, however the taxonomic classification is not only based in morphological features but rather by genealogical links between the two species [1]. Carroll [2] points out that to understand the genetic basis of different physical and behavioral characteristics between humans and other primates is a major challenge of biology. This author further questions which of the millions of base pairs are different between chimpanzees and humans, thus contributing to the separation lines. Authors like Prüfer et al [3] indicate that it is evident that two species of African apes (chimpanzees and bonobos) are genetically close to the human species, and this proximity seems to be more intense than previously expected, since humans have a higher phylogenetic similarity to these species than to other primates.

Most of the differences in gene expression between chimpanzees and humans is the result of genomic duplication, verifiable through rate mutation that would have occurred from the ancient separation of the two species [4]. According to the genetics and molecular data the chimpanzee and human clade separation must have occurred somewhere about 5 to 7 million years ago [2,5]. However, there are still gaps in this process to be understood, so that Cordeiro [6] questions the genes role on the differentiation and separation of monkeys and human clades, emphasizing that human evolution has occurred in semi-isolated populations, having evolved more rapidly, under a strong effect of natural selection together with genetic drift.

\footnotetext{
* heslley@uniformg.edu.br.
} 
Studies on the genomes of both species confirm that the molecular clock reveals a past closeness between the two species. Indeed, the genome sequence of the common chimpanzee (Pan troglodytes) has been compared with the human genome, creating a complete picture of the genetic differences that have accumulated since the divergence between these two species [7]. Wildman et al [5] showed that Furthermore, the functional part of the genome of chimpanzees and humans have more than $99 \%$ similarity therefore be closer than previously thought [4] and there is an exact parity of $95 \%$ of the DNA of chimpanzees and humans [8].

In addition to the genetic aspects other features demonstrate the close relationship between the two species, such as anatomical similarities of the bones of chimpanzees and human archaic forms (Australopithecus and Homo habilis) [9] and possible analogous cultures among chimpanzees and humans as perceived by Boesch and Tomasello [10].

Wildman et al [5] argue that the DNA evidence supporting two suggestions on the phylogeny Taxonomic: $(i)$ that all living apes should be inserted in the great Hominidae family and (ii) the genus Homo should encompass three existing species in two subgenera, Homo (Homo sapiens) and Homo Pan including troglodytes (chimpanzee) and paniscus (bonobo).

Taking into account this new classification, the present work seeks to investigate the conceptions of biology teachers from three Latin American countries, Argentina, Brazil and Uruguay, on this topic. For this purpose the question B.7 of the European project BIOHEAD-CITIZEN questionnaire was used. It asks whether respondents agree or not with the following statement: "The Chimpanzee should be included in the genus Homo, notably because 98.5\% of its DNA is identical to that of Homo sapiens". In addition to this question related to the genetic proximity between the two species, teachers were also asked about their religion in an attempt to find any association between religion and evolution/taxonomy. Considering Argentina as the country less secular, with the Catholic religion indicated in the Constitution, Brazil in an intermediate condition that is officially secular but with a strong influence of religion in society, and Uruguay with an established secular tradition [11], it was intended in this study to find whether of the teachers' declared religion is a relevant factor in their conceptions about the possible inclusion of the chimpanzee in the humans genus.

\section{METHODOLOGY}

In the present study data collection was used the BIOHEAD-CITIZEN [12; 13], this instrument is part of a wider European research ("Biology, Health and Environmental Education for better Citizenship" - FP6-STREP-CT-2004506015 CIT2; 2004-2008) and was used in 19 European countries, Africa and the Middle East. The purpose of this European research was to understand the interactions between the social context of each country and teachers' views on controversial issues such as biological evolution, especially the origin of humans, sex education, environmental and health education. One of the aspects investigated by BIOHEAD-CITIZEN project and that interest to this research refers to the relationship between religion and science in different countries and how their secularism may interfere with public education $[13,14]$.

In this study were analyzed the results from question B.7 of the questionnaire, which asks whether respondents agree or not with the following statement: "The Chimpanzee should be included in the genus Homo, notably because 98.5\% of its DNA is identical to that of Homo sapiens". They had four alternative possibilities of answers, in a Likert scale type: "I totally agree", "I agree more than disagree"; "I disagree more than agree" and "I do not agree".

Following the BIOHEAD-CITIZEN protocol [13], the questionnaires was applied to at least 50 Biology teachers in each country: 50 teachers in Buenos Aires (Argentina), 62 in Belo Horizonte (Brazil) and 57 in Montevideo (Uruguay). The sample was also similar to the study by Caldeira, Araújo and Carvalho [14] using the same instrument with Brazilian teachers. Statistical analysis of questionnaire answers used the STATISTICA 5.5 program. Firstly, it was assessed whether the level of agreement with the question differed significantly (at the level of 95\%) between the countries using the Kruskal-Wallis test. Then, the differences between pairs of countries were evaluated by the MannWhitney test.

In the analysis of the responses we were used The KVP model developed during the BIOHEAD-CITIZEN project [13] by Clément [15] for the analysis of teachers' conceptions was applied in this study about the insertion of chimpanzee in the genus Homo. The KVP model considers that one's conceptions emerge as a result of interactions between scientific knowledge $(\mathrm{K})$, value system $(\mathrm{V})$, including ideologies, beliefs and opinions and social practices (P). In this study $\mathrm{K}$ refers to teachers' knowledge about evolution and taxonomy, $\mathrm{V}$ to their religious position and $\mathrm{P}$ as their social and professional teaching practices.

Finally, the relationship between science and religion, perceived through the teachers' responses are discussed in the light of the four categories proposed by Barbour [16]: Conflict, Independence, Dialogue and Integration. 
Categories of dialogue and integration were considered as favorable to the approach of science and religion whereas categories of conflict and independence were taken as contrary to science and religion.

\section{RESULTS AND DISCUSSION}

This research intended to look at the influence of teachers' religion on their conceptions about the inclusion of chimpanzee in the genus Homo. Figure 1 shows the teachers' declared religion, as they answered to the BIOHEADCITIZEN questionnaire in each country: Argentina, Brazil and Uruguay. The percentage of Catholics in the samples decreases with the country laicity: Argentine with $58 \%$ of Catholics is the country with Catholicism inscribed in its Constitution; Brazil, with 55\%, is not officially declared Catholic but is traditionally religious; and Uruguay, with $49 \%$ of Catholics, is supposed to be a laic country. It is in Brazil that there are more Evangelicals (11\%) as compared to Uruguay (5\%) and Argentina (4\%). Interesting is the fact that among Brazilian teachers, nearly a quarter (24\%) are Spiritualists, and none of the other two countries follow this doctrine. As expected, Uruguay was the country with the highest proportion of agnostics/atheist teachers (37\%), but the high percentage in Argentina (26\%) and the lowest in Brazil (7\%) were unexpected findings, regarding previous studies [11].

Oro [11] has reported an important study on "Religion, Social Cohesion and Political System in Latin America", which data on the religion groups in Argentina, Brazil and Uruguay are shown in Table 1. Comparing the results of the present study (Figure 1) with the ones by Oro [11] (Table 1) it is possible to find similarities regarding the Catholic religion and Evangelicals, but a great difference was found about the percentage of agnostics/atheists in Argentina, $26 \%$ in this study and $2 \%$ in Oro [12]'s work. This may be due to the fact the sample used in the present study is composed of teachers whereas the one by Oro [11] was the general population and it is possible that the professional class may be more laic than the general population.

Fig 1: Biology teachers' declared religion in Argentina, Brazil and Uruguay.

Table 1. Distribution of religion in Argentina, Brazil and Uruguay.

Source Oro (2008) [11]

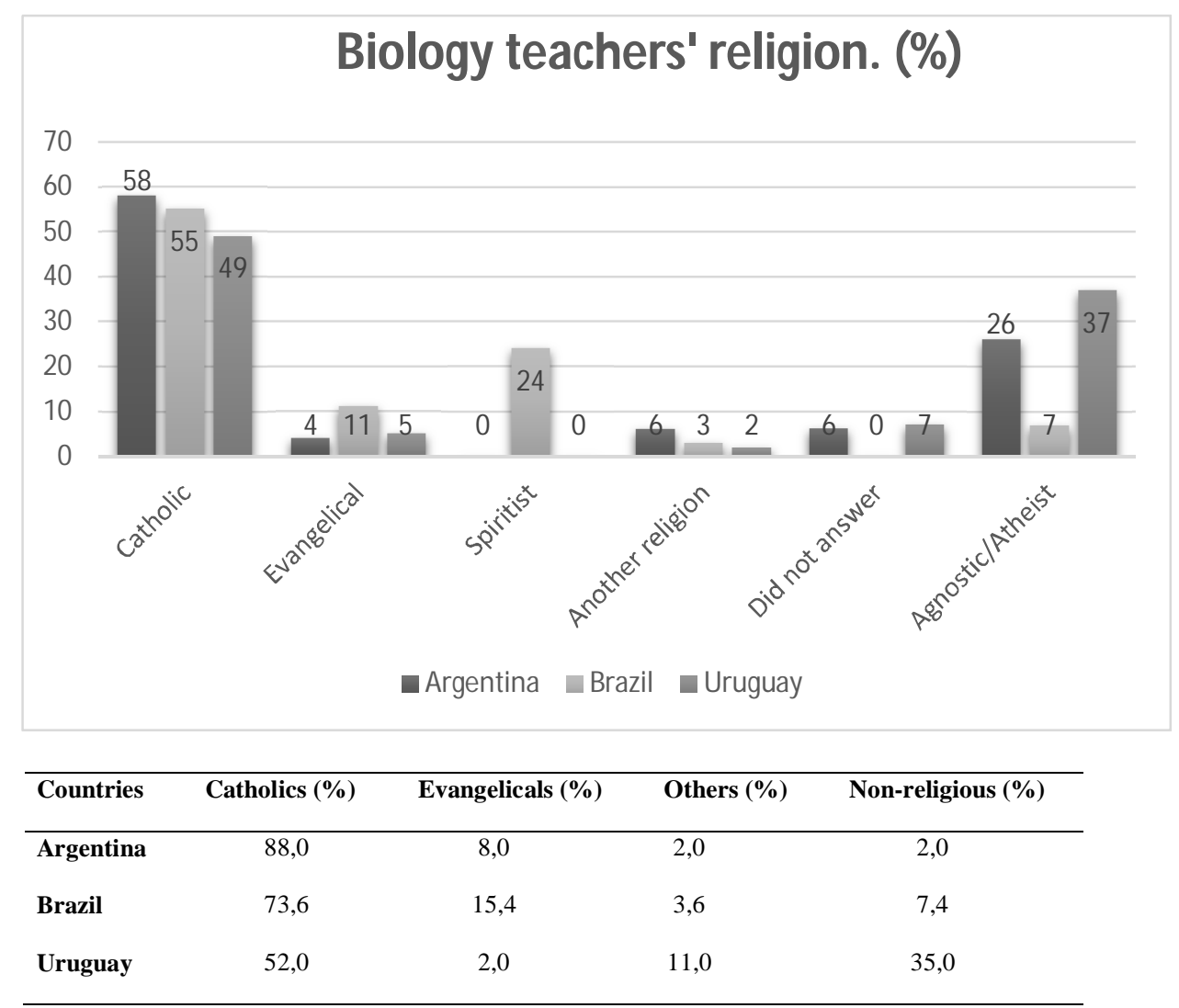


Figure 2 shows the results of teachers' answers to question B7 about the inclusion of Chimpanzee in the genus Homo due to DNA homology with Homo sapiens. The majority of the teachers of the three countries did not agree with the sentence, being higher the percentage of those from Argentina. However, no statistical differences were found between countries $(M=2.05 ; p=0: 36)$.

Figure 2. Biology teachers' answers to question B7: "The Chimpanzee should be included in the genus Homo, notably because $98.5 \%$ of its DNA is identical to that of Homo sapiens".

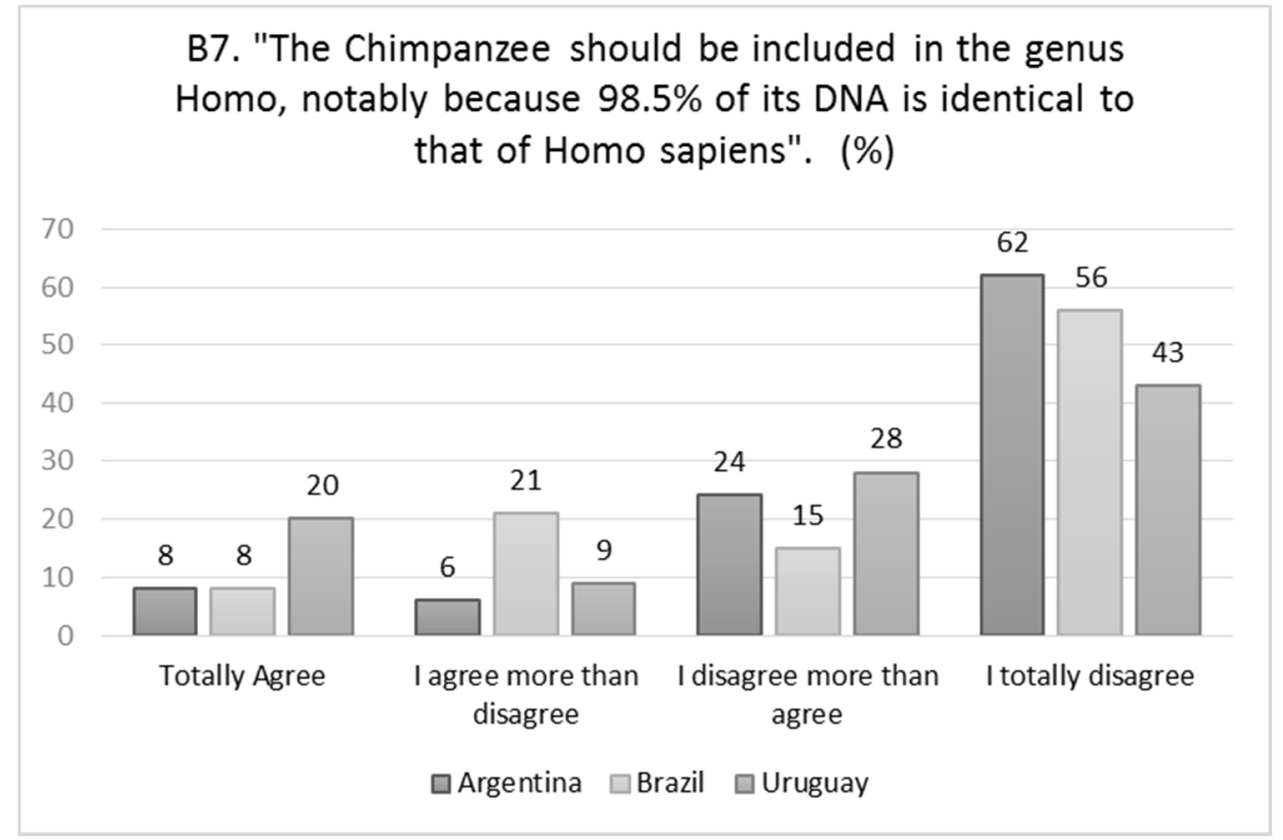

The comparative analysis of the previous issue of the results shows that respondents Argentine teachers are the most discordant in relation to the insertion of the chimp in the genus Homo, even if the difference is only marginal, less significant. Brazilians and Uruguayans in the sample are less refractory to the idea, and the Uruguayan teachers were more incisive in agreement.

This controversy about the relationship between apes is old and Bizzo [17] points out that when Huxley, disciple and personal friend of Charles Darwin, launched the book Man's Place in Nature in 1863 there was a "public reaction to the Huxley' book like the one we see today with the molecular biology data in comparative studies between humans and chimpanzees "(p. 241). Already in the work by Huxley [18] it is possible to find examples of how it was, and sill is problematic to situate the humans in relation to other species of primates: "Among the many problems which came under my consideration, the position of the man species in zoological classification was one of the most serious." (p. vii).

The answers analysis by using the KVP model, it was found high Therefore, it can be concluded in this way, because the Since teachers, in general, tended to disagree with the B7 question, it seems they do not take into consideration the recent discoveries in the field of molecular biology [19, 20] about the possibility of inclusion of the chimpanzee in the genus Homo. The analysis with the KVP model indicates that in the intersection between scientific knowledge $(\mathrm{K})$ and religious values $(\mathrm{V})$, the dogmatic factor seems to be more powerful.

In general, teachers of the three countries seem to fall mainly in the Barbour [16] category of conflict of since they show conflict between current molecular biology scientific knowledge and the religious field itself when analyzing the insertion of the chimpanzee in the genus Homo.

Our initial hypothesis of the laicism influence in this issue was not confirmed since the answers of the teachers from the three countries were almost uniform, regardless the state secularity condition. One issue to be considered for teachers' denial of the inclusion of chimpanzees in the genus Homo may be the fact that school textbooks usually present human evolution initiated by a primate, very similar to the chimpanzee [22]. This evolution in scale, in single file, raises approaches and misinterpretations suggesting that "human came from monkey", as a direct descendant of the chimpanzees. This creates successive confusions about the biological evolution and, in particular, the human origin, creating an environment of rejection to the Darwinian theory, and so opening the possibility of creationism expansion. 


\section{CONCLUSION}

From this study it can be concluded that the majority of teachers surveyed in the three countries rejected the idea of including the chimpanzee in the genus Homo, suggesting the conception of human beings having a special position in relation to other animal species, despite evidence of current molecular biology. The religiosity in all countries were similar, therefore no specific influence could be tested regarding the inclusion of chimpanzee in genus Homo.

This study indicates that it is important to study further the training of biology teachers in the three countries to verify the support of the discussions pointed out in this paper, how these teachers are being trained and their knowledge regarding molecular biology, phylogeny and evolution.

\section{Anowledgements}

The following entities provided financial support to the development of this work: University Center of Formiga/MG" (Brazil), the Oxford University (UK), John Templeton Foundation (USA) and the research centre CIEC of the University of Minho (Portugal).

\section{References}

[1] Ingold, Tim. (1995) Humanidade e animalidade. Revista Brasileira de Ciências Sociais, v. 10, n. 28, p. 39-53.

[2] Carroll. Sean B. (2003). Genetics and the making of Homo sapiens. Nature, v. 422. n. 6934. p. 849-857.

[3] Prüfer, Kay et al. (2012). The bonobo genome compared with the chimpanzee and human genomes. Nature, v. 486, n. 7404, p. 527-531.

[4] Cheng, Ze et al. (2005) A genome-wide comparison of recent chimpanzee and human segmental duplications. Nature, v. 437, n. 7055, p. 8893.

[5] Wildman, Derek E. et al. (2003) Implications of natural selection in shaping $99.4 \%$ nonsynonymous DNA identity between humans and chimpanzees: Enlarging genus Homo. PNAS, v. 100, n. 12, p. 7181-7188.

[6] Cordeiro, Antonio Rodrigues. (2008). Gênese da vida humana. Ciência e Cultura, v. 60, n. SPE1, p. 60-62.

[7] Sequencing, The Chimpanzee et al. (2005) Initial sequence of the chimpanzee genome and comparison with the human genome. Nature, v. 437, n. 7055, p. 69-87.

[8] Britten. Rov J. (2002) Divergence between samples of chimpanzee and human DNA sequences is 5\%, counting indels. Proceedings of the National Academy of Sciences, v. 99, n. 21, p. 13633-13635.

[9] Deloison, Yvette. (1997) Description d'un astragale fossile de primate et comparaison avec des astragales de chimpanzés, d'Homo sapiens et d'hominidés fossiles: Australopithèques et Homo habilis. Comptes rendus de l'Académie des sciences. Série 2. Sciences de la terre et des planètes, v. 324, n. 8, p. 685-692.

[10] Boesch, Christophe; Tomasello, Michael. (1998) Chimpanzee and human cultures. Current anthropology, v. 39, n. 5, p. $591-614$.

[11] Oro, Ari Pedro. (2008) "Religião, Coesão Social e Sistema Político na América Latina." Religion, Social Cohesion and Political System in Latin America. IFHC / CIEPLAN. Sao Paulo, Brazil, and Santiago de Chile. Available at: <http://creativecommons.org/licenses/by-nc$\mathrm{nd} / 2.5 / \mathrm{br} />$.

[12] Carvalho, Graça Simões. (2004) Biology, health and environmental education for better citizenship. In E. Commission (Ed.), Research \& Innovation - Socio-Economic Sciences and Humanities: European Commission.

[13] Carvalho, Graça Simões and Clément, Pierre. (2007) Projecto 'Educação em Biologia, Educação para a Saúde e Educação Ambiental para uma melhor cidadania': análise de manuais escolares e concepções de professores de 19 países (europeus, africanos e do próximo oriente). Revista Brasileira de Pesquisa em Educação em Ciências, 7:2, 1-21.

[14] Caldeira, Ana Maria de Andrade; Araújo, Elaine Sandra N. Nabuco and Carvalho, Graça Simões. [2012] Creationism and evolution views of Brazilian teachers and teachers-to-be. Journal of Life Sciences, 6:1, 99-109.

[15] Clément, P. (2006). Didactic transposition and the KVP model: conceptions as interactions between scientific knowledge, values and social practices. Proceedings of ESERA Summer School 2006, IEC, Braga (Portugal), pp.9-18.

[16] Barbour, Ian. G. (1990) Religion in an Age of Science. San Francisco: Harper San Francisco.

[17] Bizzo, Nélio. (2006) O berço do darwinismo e suas promessas para o homem. Filosofia e História da Biologia, v. 1, p. $229-246$.

[18] Huxley, Tomas. H. (1901) Man's Place in Nature and Others Anthropological Essay. London, MacMillan and Co. New York: MacMillan Company. Available at https://ia700504.us.archive.org/5/items/a588317300huxluoft/a588317300huxluoft.pdf

[19] Borja, Caroline. (2007) Desconstruindo o Homem. Comciência, Revista Eletrônica de Jornalismo Científico, 2007. http://www.comciencia.br/comciencia/?section=8\&edicao=31\&id=364.

[20] Rapchan, Eliane Sebeika. (2004) Os parentes de nossos parentes: um ensaio sobre a sociedade e as culturas dos chimpanzés sob uma perspectiva antropológica. Revista de Etologia. V.6, n.2, São Paulo, dez, p. 101-117.

[21] Mota, Helenadja Santos. (2013) Evolução biológica e religião: atitudes de jovens estudantes brasileiros. Tese de Doutorado. Universidade de São Paulo.

[22] Santos, Charles Morphy D.; Klassa, Bruna. (2012) Despersonalizando o ensino de evolução: ênfase nos conceitos através da sistemática filogenética. Educação: Teoria e Prática, v. 22, n. 40, p. 62-80. 